\title{
Jerzy Leśniak, Nowa encyklopedia sądecka, Drukarnia GOLDRUK, Nowy Sącz 2017, ss. 1012.
}

Spośród wielu definicji regionalizmu za zasadną przyjąć można zaproponowaną, przed laty, przez autorów Słownika języka polskiego opracowanego pod redakcją Witolda Doroszewskiego. Traktuje ona regionalizm jako „(...) ruch umysłowy dążący do ożywienia życia kulturalnego i naukowego na prowincji (...)". Mówiąc nieco inaczej oznacza on dążenie do obudzenia w poszczególnych dzielnicach kraju samoistnego ruchu umysłowego i kulturalnego (Stownik języka polskiego, tom 7, PWN 1965, s. 887). Ten ważny dla naszego kraju ruch, w sferze umysłowej, zaznaczył się poważnymi, rzec można - bez cienia przesady - ilościowo imponującymi, a co do jakości fenomenalnymi osiągnięciami. Przykładem są liczne bibliografie regionalne i lokalne, ogromna ilość pism naukowych i czasopism wydawanych w wielu miejscowościach, coraz liczniejsze - niejednokrotnie kilkutomowe - monografie („dzieje”) historyczne miast i miasteczek, a nawet wsi, regionalne i lokalne słowniki biograficzne zawierające opis życia i działalności osób zasłużonych, przewodniki i informatory turystyczne traktujące o miejscowościach i regionach, słowniki gwary ludowej, wydawnictwa albumowe ukazujące piękno poszczególnych miejscowości i istniejących tam osobliwości geograficznych, a także opis lokalnych wydarzeń (uroczystości).

Do wymienionych dzieł dodać trzeba opublikowane monografie wielu obiektów (np. zabytkowych świątyń, oryginalnych w formie architektonicznej pałaców i dworów, starych wyrobisk i obiektów gospodarczych, historycznych cmentarzy i in.) oraz wyróżniających się działalnością instytucji (szkoły średnie i uczelnie wyższe, formacje wojskowe, muzea, biblioteki, parafie, fabryki, wydawnictwa książkowe i prasowe i in.), stowarzyszeń regionalnych i lokalnych, a także biografie znanych (pojedynczych) osób urodzonych i pracujących w różnych miejscowościach.

Niewątpliwie najmłodszą, bo intensywnie rozwijaną dopiero pod sam koniec XX w. i z początkiem XXI w., a przy tym i - jak się wydaje - najwyższą 
formą regionalizmu naukowego, jest opracowywanie i wydawanie encyklopedii regionalnych. Są to wydawnictwa informacyjne zawierające wiadomości ze wszystkich dziedzin życia dotyczące danego terytorium geograficznego lub jednej konkretnej miejscowości. W naszym kraju dynamiczny ruch naukowy w tym zakresie zapoczątkowało przygotowanie i wydrukowanie Encyklopedii Warszawy (1994, około 7 tys. haseł, 1071 ss.) oraz Encyklopedii tatrzańskiej Marii i Witolda Paryskich (1995, około 5,8 tys. haseł, 1553 ss.), a następnie Encyklopedii Krakowa (2000, prawie 5,5 tys. haseł, 1136 ss.), Encyklopedii Szczecina (2000, 2 tomy - razem 1517 ss.), nieco później (w latach 2003-2010) uzupełnionej i zaktualizowanej „Suplementem” w trzech tomach. Konkurencją dla nich stałą się kolejna „Encyklopedia Szczecina” pod red. Tadeusza Białeckiego (2016).

Zapoczątkowany przez te wydawnictwa ruch naukowy i edytorski szybko doszedł do dużych osiągnięć redakcyjnych i publikacyjnych. Jego efektem w chwili obecnej (2018 r.) jest ukazanie się kilkudziesięciu (nie licząc objętościowo małych, a co do treści skromnych) okazałych encyklopedii miast i regionów. Przykładem jest Encyklopedia Wrocławia pod red. Jana Harasimowicza (2006, 1060 ss..), Józefa Witka Encyklopedia miasta Mielca (trzy tomy z lat 2004-2008), Popularna encyklopedia Ziemi Kłodzkiej pod red. Janusza Laska i Mieczysława Kowalcze (cztery tomy wydrukowane latach 2009-2011), Encyklopedia Gniezna i Ziemi Gnieźnieńskiej (2011, 772 ss.) wydana staraniem Towarzystwa Miłośników tego miasta oraz (encyklopedie) inne.

Wskutek sygnalizowanej dynamiki stosunkowo szybko zagęszcza się sieć miast i regionów uzyskujących okazałe encyklopedie. Na linii prostej od Gdyni (Encyklopedia Gdyni, 2006) do Tatr (Encyklopedia tatrzańska, 1995) posiada ją Gdańsk, Warszawa i Kraków. Wędrując zaś od Polic nad Zalewem Szczecińskim (Encyklopedia Polic, 2015) w rejon Mielca (Encyklopedia miasta Mielca, 2004-2008) czy Zamościa (Andrzej Kędziora, Encyklopedia miasta Zamościa, 2012, wydanie drugie) natrafić można na takie miasta z opublikowanymi encyklopediami jak: wspomniany Szczecin, Gorzów Wielkopolski (Jerzego Zysnarskiego Encyklopedia Gorzowa, 2007), Wrocław (Encyklopedia Wrocławia, 2006), Chorzów (Encyklopedia Chorzowa, 2009), Kraków (Encyklopedia Krakowa, 2000) i Tarnów (Encyklopedia Tarnowa, 2010). Tylko na Podkarpaciu okazałymi encyklopediami cieszą się mieszkańcy trzech miast położonych blisko siebie: wspomniany Mielec, Rzeszów (Encyklopedia Rzeszowa, 2004, 839 ss.) i Jasło (Encyklopedia Jasła, 2010, 717 ss.).

Sygnalizowany ruch naukowy opracowywania i publikowania encyklopedii regionalnych przelał się nawet na tereny kresowe. Przykładem Ency- 
klopedia Kresów - Wydawnictwo Ryszarda Kluczyńskiego ze „Słowem wstępnym" Stanisława Lema (Kraków, b.r.w, 559 ss.) oraz monumentalna, bogato ilustrowana, ukraińska Encyklopedia Lwowa (cztery tomy z lat 2007-2012).

Omawiany zbiór polskich encyklopedii regionalnych w 2017 r. powiększył się o kolejne dzieło tego typu, jakim jest Jerzego Leśniaka Nowa encyklopedia sądecka, opublikowana przez znaną nowosądecką Drukarnię GOLDRUK Wojciecha Golachowskiego. Jest to dzieło monumentalne (około 16 tys. haseł i blisko 8 tys. zdjęć, liczące 1012 ss.). Dzieło opracowane zostało na rocznicę 725-lecia miasta Nowego Sącza i jest ponad dwukrotnym powiększeniem wydanej w 2000 r. Encyklopedii sq̨deckiej (471 ss.) opracowanej przez Jerzego Leśniaka wspólnie $z$ ojcem Augustynem Leśniakiem i przy pomocy syna Karola - wtedy studenta arabistyki w Uniwersytecie Warszawskim.

Trzeba przyznać, że Nowy Sącz i Sądecczyzna, przez dynamikę rozwoju „zasłużyły” na poświęcenie im tak monumentalnego dzieła. W chwili druku Nowej encyklopedii sq̨deckiej miasto (powiat grodzki) liczyło prawie 84 tys. mieszkańców, zaś w powiecie (ziemskim) nowosądeckim (5 miast, 249 wsi) mieszkało 213 tys. ludności. Chlubą regionu są znane zakłady produkcyjne (Newag S.A. - produkcja nowoczesnych składów pociągów kursujących nie tylko w naszym kraju, firma „Wiśniowski” produkująca bramy przemysłowe i garażowe, drzwi i systemy ogrodzeniowe - eksporter tych wyrobów do wielu krajów świata, „Fakro” - firma nr 2 w produkcji okien dachowych na świecie, „Konspol” - potentat na rynku europejskim w produkcji wędlin drobiowych, „Koral” - największe w Polsce „imperium lodowe” konkurujące $z$ powodzeniem ze światowymi potentatami w tym zakresie, i wiele innych). Symbolem znaczenia gospodarczego wymienionego miasta i regionu jest doroczne międzynarodowe Forum Ekonomiczne w Krynicy Zdroju.

Nowy Sącz to miasto o bardzo bogatej historii mocno zespolonej z dziejami naszego kraju. Założone w 1292 r. przez króla czeskiego Wacława II Przemyślida ( $w$ intencji zabezpieczeniu swojego państwa przed ewentualnymi atakami z północy) przez wielowiekowe zmagania o bezpieczeństwo i dobro Polski dowiodło ogromnego patriotyzmu. W 1311 r. mieszczanie sądeccy poparli Władysława Łokietka w jego sporze z wójtem krakowskim Albertem, przyczynili się do zjednoczenia przez niego ziem polskich i jego koronacji. Tam, w zamku wybudowanym za czasów Kazimierza Wielkiego, wiosną 1410 r. odbyła się narada Władysława Jagiełły z wielkim księciem litewskim Witoldem, w czasie której opracowano skuteczny plan wojny z Krzyżakami. W tym samym zamku w latach 1469-1470 edukowani byli, początkowo przez Jana Długosza, a później przez humanistę włoskie- 
go Kallimacha, synowie Kazimierza Jagiellończyka - późniejsi królowie Polski i Litwy. W dniu 12 grudnia 1655 miasto wyzwoliło się własnymi siłami z potopu szwedzkiego dając początek zrywowi wyzwoleńczemu narodu polskiego (13 dni po tym Szwedzi rozpoczęli odwrót spod Jasnej Góry). Po prawie 250 latach po tym fakcie (w grudniu 1916 r.) w Nowym Sączu Józef Piłsudski sformował I Brygadę Legionów (w tym mieście najprawdopodobniej powstał też hymn legionowy My Pierwsza Brygada). Miasto to - jako pierwsze w Polsce - przyznało Komendantowi Legionów tytuł honorowego obywatela (miasta).

Poza tymi tradycjami współczesna Sądecczyzna to od lat znany region lecznictwa balneologicznego (Krynica Zdrój, Muszyna, Żegiestów), turystyki i krajoznawstwa, sportów zimowych i kajakarstwa górskiego.

Gospodarce sądeckiej dorównuje dynamiką miejscowe szkolnictwo. Aktualnie w mieście czynne są 32 przedszkola publiczne i kilka prywatnych, działa 25 (w tym cztery prywatne) szkół podstawowych, 3 licea ogólnokształcące, 20 (ilość ta często się zmienia) średnich szkół zawodowych kształcących w wielu zawodach i specjalnościach. Dumą władz miasta są dwie szkoły wyższe (przed laty w mieście było 5 filii i punktów konsultacyjnych krakowskich szkół wyższych, do 2011 r. działała Wyższa Szkoła Przedsiębiorczości): Państwowa Wyższa Szkoła Zawodowa i - wyrosła ze współpracy polsko-amerykańskiej - Wyższa Szkoła Biznesu - National Louis University. Obie kształcą studentów na poziomie licencjackim, magisterskim i podyplomowym.

Miasto i region nowosądecki to także poważny ośrodek życia kulturalnego (biblioteki, oryginalne muzea, atrakcyjne zespoły instrumentalne - w tym Orkiestra Reprezentacyjna Straży Granicznej zachwycająca publiczność wykonywaniem musztry paradnej w rytm muzyki wojskowej i regionalnej - i chóralne). W Sądecczyźnie organizowane też są znane ogólnopolskie i regionalne imprezy artystyczne (np. Festiwal Ady Sari w Starym Sączu, Festiwal Kiepurowski w Krynicy Zdroju) oraz sportowe (hokej i saneczkarstwo w Krynicy, siatkówka w Muszynie, kajaki i piłka nożna w Nowym Sączu).

Autorem wspomnianej Nowej encyklopedii sq̨deckiej jest Jerzy Leśniak urodzony (1957 r.) i wychowany w Nowym Sączu, absolwent (najstarszego) miejscowego I Liceum Ogólnokształcącego im. Jana Długosza (zał. w 1818 r. jako jedno z 12 w Galicji, przy znaczącym udziale klasztoru cystersów w Szczyrzycu), a następnie studiów z zakresu nauk politycznych i dziennikarstwa Uniwersytetu Jagiellońskiego. Jerzy Leśniak po studiach całe życie pracował jako dziennikarz w Nowym Sączu. Początkowo jako reporter miejscowego miesięcznika „Dunajec”, a następnie sądeckich oddziałów: „Gaze- 
ty Krakowskiej” i krakowskiego „Dziennika Polskiego” oraz „Sądeczanina”. W latach następnych był redaktorem naczelnym tygodnika „Echo” w Nowym Sączu oraz kwartalnika „Nowy Sącz”. Współpracował z „Almanachem Sądeckim” (miesięcznik) i „Dobrym Tygodnikiem Sądeckim”. Został też lokalnym korespondentem prasy polonijnej w USA. W 2007 r. Jerzy Leśniak wszedł w skład zespołu redakcyjnego zasłużonego dla Sądecczyzny „Rocznika Sądeckiego", gdzie nie tylko wyróżniał się jako autor wartościowych artykułów, ale także jako niezwykle staranny sekretarz redakcji. Osiągnięcia w pracy dziennikarskiej szybko doprowadziły go do funkcji rzecznika prasowego Urzędu Miasta Nowego Sącza, sekretarza Klubu Przyjaciół Ziemi Sądeckiej (stowarzyszenie ogólnopolskie), współpracy z Regionalną Telewizją Kablową w Nowym Sączu, a także do stanowiska wykładowcy dziennikarstwa w nowosądeckiej Państwowej Wyższej Szkole Zawodowej.

Głównym jednak rodzajem działalności twórczej Jerzego Leśniaka była realizacja badań naukowych, pisanie i publikowanie książek. Napisał ich (jako autor i współautor) 25. Tematyka wszystkich związana jest z Nowym Sączem i Sądecczyzną. Dotyczy wielu spraw tego atrakcyjnego geograficznie, dynamicznego gospodarczo i osobliwego kulturowo regionu. Począwszy od 2000 r. w zasadzie co roku wydawał jedną obszerną książkę, dając tym dowód ogromnych pasji, benedyktyńskiej pracowitości oraz wielkiej pisarskiej staranności. Przykładowo wymienić można: wspomnianą już Encyklopedię sq̨deckq (2000), Panoramę kultury sq̨deckiej (2007), Drugq̨ młodość Starego Sqcza (2010), 101 sqdeczan (2012), Samorzadnq Korzennq 1990-2015 (2015), Panoramę portu sq̨deckiego (2016, dwa obszerne tomy), Sto scen z historii Nowego Sq̨cza 1292-2017 (2017). Oprócz książek Jerzy Leśniak opracowywał obszerne rozdziały traktujące o różnych zjawiskach w (zbiorowych) monografiach miejscowości sąsiednich (np. Podegrodzie i Gmina Podegrodzka, 2014). Zaletą jego książek jest umiejętne połączenie tekstu z piękną ilustracją - historyczną i współczesną. To połączenie upoważnia do stwierdzenia, że redaktor Jerzy Leśniak wypracował w swoich publikacjach oryginalny wartościowy przekaz słowno-ikonograficzny nadający oryginalność jego dziełom i sprzyjający recepcji ich treści. Tematyka, jak i wspomniane zalety jego pisarstwa, uzasadniają zaliczenie Jerzego Leśniaka do grona najbardziej twórczych regionalistów w naszym kraju.

Przygotowując Nowq encyklopedię sądeckq̨ Jerzy Leśniak uważnie (w wielu przypadkach ponownie) przestudiował ogromne piśmiennictwo na temat przeszłości i teraźniejszości Nowego Sącza oraz Sądecczyzny, począwszy od tak pomnikowych dzieł jak: Szczęsnego Morawskiego Sq̨decczyzna (1865), ks. Jana Sygańskiego Historia Nowego Sacza od wstapienia dynastii Wazów 
do pierwszego rozbioru Polski (1901-1902, t. 1-3) oraz trzytomowych Dziejów miasta Nowego Sącza (1992-1996), przez liczne publikacje monograficzne ukazujące genezę i rozwój różnych zjawisk w Sądecczyźnie, po ogromną ilość artykułów i rozpraw publikowanych w książkach i piśmiennictwie naukowym (w tym w 45 numerach „Rocznika Sądeckiego”, za lata 1939-2017). Autor przeprowadził też wiele szczegółowych kwerend archiwalnych oraz przeanalizował sporo tekstów udostępnionych mu przez innych badaczy. Elementem metodologii naukowej Jerzego Leśniaka była ankieta osobowa skierowana do wielu ludzi z Nowego Sącza i Sądecczyzny na temat ich przeszłości oraz działalności zawodowej i społecznej.

Opracowana z tak zebranych materiałów Nowa encyklopedia sq̨decka zawiera zróżnicowane - co do treści i struktury redakcyjnej - rodzaje haseł. Pierwsze to liczne biogramy osób zarówno urodzonych, całe życie mieszkających oraz pracujących w Nowym Sączu i Sądecczyźnie, osób przybyłych w różnych okolicznościach i z powodu rozmaitych przyczyn do tego miasta oraz regionu, jak również ludzi urodzonych i wychowanych w Sądecczyźnie, a pełniących ważne funkcje w kraju i za granicą. Przykładem tych ostatnich: marszałkowie sejmu (Stanisław Małachowski - czteroletniego, Józef Oleksy: 1993-1995 i 2004-2005), ministrowie (Bronisław Pieracki, Bolesław Faron, Andrzej Czerwiński), generałowie wojska polskiego (Jan Romer, Józef Giza, Józef Kustroń, Franciszek Gągor), dyplomaci (Kazimierz Kurnikowski - konsul RP w Nowym Jorku, Jerozolimie i in., Marian Chodacki - ostatni Komisarz Generalny RP w Wolnym Mieście Gdańsku, Stanisław Skrzeszewski - ambasador RP w Paryżu po II wojnie światowej), wybitni pracownicy nauki (Henryk Barycz - historyk kultury i nauki, Jan Słowikowski - chirurg, współorganizator w czasie okupacji ucieczki emisariusza J. Karskiego ze szpitala w Nowym Sączu, Tadeusz Popiela - chirurg, Maria Olech - współczesny botanik i polarnik z UJ, której imieniem nazwano w 2008 r. jedno ze wzgórz w zachodniej części Antarktyki), wybitni artyści scen polskich (Danuta Szafarska, Zofia Rysiówna, Katarzyna Zielińska), artyści malarze (Bolesław Barbacki, Maria Ritter, Jadwiga Marschalko-Kosalowa), dobrze wpisani w dziej Kościoła teologowie (Franciszek Ksawery Wierzchlejski metropolita Lwowa, uczestnik Soboru Watykańskiego I, Józef Kumor, twórca - w 1992 - nowego podziału administracji kościelnej w Polsce, ks. bp Józef Gucwa - autor wojennych wspomnień $Z$ leśnych koszar do kapłaństwa), wybitni inżynierowie i architekci, zasłużeni nauczyciele, operatywni działacze kultury i wielu innych. Z biogramów tych osób dowiedzieć się można, ile Sądecczyzna wniosła w rozwój Polski i jak mocno związana jest jej przeszłość z losami naszego kraju. 
Drugi rodzaj tekstów zamieszczonych w Nowej encyklopedii sq̨deckiej to treściwe monografie obiektów historycznych i znaczących budynków użyteczności publicznej (ratusz, sądeckie ulice, osiedle Stara Kolonia, sądeckie mosty, obiekty sportowe, sądeckie pomniki), przedsiębiorstw przemysłowych, instytucji gospodarczych i usługowych (np. spółdzielnie sądeckie), szkół i instytucji kultury (muzeów, bibliotek, domów kultury, zespołów artystycznych), klubów sportowych, instytucji administracyjnych, stowarzyszeń kultury i partii politycznych, grup zawodowych i społecznych (adwokaci sądeccy, proboszczowie sądeckich parafii, posłowie nowosądeccy, internowani i aresztowani w stanie wojennym), wydawnictw, prasy i książek, miast i wielu wsi Sądecczyzny, sądeckich parafii, formacji wojskowych (np. I Pułk Strzelców Podhalańskich) i partyzanckich (oddział partyzancki „Tatara” $i$ in.) cmentarzy, tablic pamiątkowych oraz in.

Trzeci rodzaj tekstów zamieszczonych w omawianej Nowej encyklopedii sq̨deckiej to - na ogół - szczegółowe opisy ważnych wydarzeń, jakie miały miejsce w Sądecczyźnie w ciągu ostatnich setek i dziesiątków lat. Przykładem obchody jubileuszowe konstytucji 3 Maja w mieście (od 1891 r.) i okolicach, wybory parlamentarne w Sądeckiem, klęski żywiołowe (powodzie, pożary), wojny światowe w Nowym Sączu, kanonizacja księżnej Kingi w Starym Sączu w dniu 19 czerwca 1999 r. przez Jana Pawła II (zgromadziła w jednym miejscu największą ilość ludności w dziejach Sądecczyzny). Opisy wielu tych wydarzeń uzupełnione zostały ogromną ilością nazwisk osób z tymi wydarzeniami związanych. Są to np. wykazy: starostów, spisy radnych miasta, powiatu, poszczególnych miast i gmin Sądecczyzny (od II wojny światowej), imienne wyniki wyborów (obie tury) na prezydenta miasta Nowego Sącza z lat 1990-2015, wykazy osób wyróżnionych medalem „Zasłużeni dla Ziemi Sądeckiej" (od 2003 r.), nazwisk dyrygentów i członków orkiestr sądeckich ze wskazaniem nazwy instrumentów, na których grali wymienieni orkiestranci, nazwiska i życiorysy sądeckich więźniarek obozu Ravensbrück, nazwiska sądeckich posłów i senatorów (począwszy od wyborów w 1989 r.), działaczy poszczególnych partii politycznych, dyrektorów i nauczycieli szkół, proboszczów sądeckich parafii oraz wielu innych.

Integralną część omawianego dzieła stanowi bogata ikonografia dobrze zespolona w tekstem słownym. Tworzą ją gromadzone przez dziesięciolecia przez Jerzego Leśniaka fotografie postaci i obiektów budownictwa (historycznych i współczesnych), krajobrazu, pomników i tablic pamiątkowych, uroczystości i pamiątek po nich, planów miast i miejscowości, fotografie książek i czasopism (tytułowe strony). Wiele z tych zdjęć wykonał sam Autor posługujący się po mistrzowsku aparatem fotograficznym. Dobre roz- 
szerzenie treści wielu haseł stanowią także wykonane przez Autora wykresy i tabele.

Tak zredagowana encyklopedia jest uporządkowanym (alfabetycznie i przekrojowo) zbiorem podstawowych wiadomości ze wszystkich dziedzin życia z minionych epok i współcześnie dotyczących miasta Nowego Sącza, 5 miast i 16 gmin wiejskich wchodzących w skład powiatu nowosądeckiego. Ukazuje ona charakteryzowane w niej procesy i zdarzenia jako regionalną i lokalną egzemplifikację zjawisk ogólnopolskich, eksponując jednak odmienność i regionalną specyfikę wielu z nich. Ukazuje ona miasto Nowy Sącz jako centrum administracyjne (w latach 1975-1998 siedziba województwa nowosądeckiego), gospodarcze, edukacyjne i kulturowe niezwykle atrakcyjnego regionu. Regionu, który rozwijał się dynamicznie w czasach przychylności dla niego rządzących krajem (czasy księżnej Kingi, epoka Jagiellonów, zgoda władz centralnych w 1956 r. na „eksperyment sądecki”). Podupadał, gdy tej przychylności brakowało, nastały zabory i wybuchały wojny. Ale i wtedy, w trudnych czasach obywatele miasta i ludzie $z$ otaczającego je regionu mobilizowali się, podejmowali działania dające (fakt, że czasem dopiero po latach), powody do dumy i satysfakcji.

Nowa encyklopedia sq̨decka jest - co z uznaniem podkreślił jej recenzent prof. dr hab. Bolesław Faron - wynikiem benedyktyńskiej pracy (z reguły encyklopedie są efektem pracy zespołu autorów) jednego człowieka. Jest ona bezcennym kompendium wiedzy o wydarzeniach historycznych i współczesnych przeobrażeniach Sądecczyzny, jej środowisku geograficznym, życiu społecznym, problemach gospodarczych, oświatowych i kulturalnych. Jest niezwykle cennym dokumentem wysiłku i dokonań ludzi oraz tworzonych przez nich instytucji działających w tym zasłużonym dla naszego kraju regionie.

Bez znajomości wielu faktów wymienionych w Nowej encyklopedii sq̨deckiej nie można mówić o pełnej znajomości historii naszego kraju. Przykładem wspomniana już narada z wiosny 1410 r. króla Władysława Jagiełły z wielkim księciem litewskim Witoldem na zamku sądeckim, w czasie której opracowali oni plan rozprawy wojennej z Krzyżakami. Trudno też dokładnie poznać genezę pierwszego rozbioru Polski bez zagłębienia się w okoliczności grabieży (pod wpływem wyraźnej zachęty „radcy” i „eksperta” dworu wiedeńskiego Józefa Töröka z Szendrö - narodowości węgierskiej) w 1770 r. przez Austrię Spiszu oraz znacznej części starostw czorsztyńskiego, sądeckiego i nowotarskiego, a następnie, na mocy traktatu zawartego 24 lipca 1770 r. w (podsądeckim) Mogilnie, włączonej do Królestwa Węgierskiego (s. 497). Nie da się chwalić znajomością dziejów Legionów bez wiedzy o oko- 
licznościach i warunkach sformowania w Nowym Sączu, w grudniu 1916 r., Pierwszej Brygady. Nie można się też szczycić dokładną znajomością dziejów polskiego radia nie wiedząc o pierwszej transmisji wydarzenia spoza Warszawy. Treścią jej było przemówienia premiera M. Zyndrama-Kościałkowskiego w dniu 21 czerwca 1934 r. z odbywającego się w Nowym Sączu pogrzebu ministra Bronisława Pierackiego (zmarłego w następstwie zamachu). Nawet dzisiejszy pasjonat pieśni biesiadnej nie może się szczycić rzeczywistą znajomością jej przeszłości nic nie wiedząc o ks. Franciszku (Borgiaszu) Leśniaku, starosądeckim katechecie (1871-1873) i jego wkładzie w powstanie pieśni Uptywa szybko życie (nowsza wersja Jak szybko mijaja chwile). Podobnych przykładów poszerzenia i uzupełnienia wiedzy ogólnej przez zapoznanie się z różnymi hasłami Nowej encyklopedii sądeckiej przytoczyć można znacznie więcej. Dowodzi to, że omawiana Nowa encyklopedia sądecka służyć będzie nie tylko rodowitym Sądeczanom. Jest ona także skarbnicą wiedzy dla osób z innych części kraju zainteresowanych poznaniem tego pięknego regionu oraz jego wkładu w dzieje naszego kraju.

Omawiana encyklopedia stała się nie tylko zwieńczeniem, ale i zamknięciem 40-letniej, bogatej i intensywnej twórczości naukowej oraz publicystycznej Jerzego Leśniaka. Autor encyklopedii zmarł nagle (20 sierpnia 2017 r.), dokładnie kilka dni po jej złożeniu do druku (dokonując korekty kilku ostatnich jej stron). Nie doczekał jej publikacji i należnych mu z tego powodu splendorów. Za swoją pasję zapłacił cenę najwyższą. Dzieło jego życia zostanie jednak trwałym i monumentalnym pomnikiem regionalizmu polskiego. 